\title{
What Happens When Insurers Make the Insurance Laws? State Legislative Agendas and the Occupational Makeup of Government
}

\author{
Eric Hansen \\ Loyola University Chicago, ehansen4@luc.edu \\ Nicholas Carnes \\ Duke University \\ Virginia Gray \\ University of North Carolina at Chapel Hill
}

Follow this and additional works at: https://ecommons.luc.edu/politicalscience_facpubs

Part of the Political Science Commons

Author Manuscript

This is a pre-publication author manuscript of the final, published article.

\section{Recommended Citation}

Hansen, Eric; Carnes, Nicholas; and Gray, Virginia. What Happens When Insurers Make the Insurance Laws? State Legislative Agendas and the Occupational Makeup of Government. State Politics and Policy Quarterly, 19, 2: 155-179, 2018. Retrieved from Loyola eCommons, Political Science: Faculty Publications and Other Works, http://dx.doi.org/10.1177/1532440018813013

This Article is brought to you for free and open access by the Faculty Publications and Other Works by Department at Loyola eCommons. It has been accepted for inclusion in Political Science: Faculty Publications and Other Works by an authorized administrator of Loyola eCommons. For more information, please contact ecommons@luc.edu. (c) (i) $९$

This work is licensed under a Creative Commons Attribution-Noncommercial-No Derivative Works 3.0 License. (C) The Authors, 2018. 


\title{
What Happens When Insurers Make Insurance Laws?
}

State Legislative Agendas and the Occupational Makeup of Government

\author{
Eric Hansen \\ Assistant Professor of Political Science \\ Department of Political Science \\ Loyola University Chicago \\ ehansen4@luc.edu \\ Nicholas Carnes \\ Assistant Professor of Public Policy and Political Science \\ Sanford School of Public Policy \\ Duke University \\ nicholas.carnes@duke.edu \\ Virginia Gray \\ Robert Watson Winston Distinguished Professor of Political Science \\ Department of Political Science \\ University of North Carolina at Chapel Hill \\ vagray@email.unc.edu
}

October 3, 2019

The authors thank Nathaniel Birkhead, Anthony DiMaggio, James Monogan, Marjorie Sarbaugh-Thompson, Kelsey Shoub, and participants in the 2017 MPSA Annual Meeting and the 2017 State Politics \& Policy Conference for their helpful comments. The authors are grateful for research assistance from Tim Dinehart, Mason Dufresne, Dan Gustafson, David Joyner, Melissa Lee, Amanda Lewellyn, Katie Pischke, and Adam Weber. 


\begin{abstract}
Do the occupational backgrounds of politicians affect the government's agenda? Businesses have long thought so. The first occupational data on state legislators were collected by the Insurance Information Institute, an interest group representing major insurance companies. In this paper, we test one potential motive for these kinds of efforts: the idea that the occupational makeup of governments affects the agendas they pursue, an argument that has been largely neglected in research on politicians' occupational backgrounds. We focus here on the insurance industry. Using original data, we find that state legislatures with more former insurers consider fewer bills regulating insurance (negative agenda control), that former insurers play a disproportionate role in drafting the insurance bills that are introduced (positive agenda control), and that the bills former insurers introduce tend to be more favorable to the industry than those that their colleagues introduce (positive agenda control). The occupational makeup of legislatures may indeed affect their agendas, as industry groups have long suspected.
\end{abstract}

Keywords: descriptive representation; insurance; social class; occupation; agendas; state politics 
Does it matter what professional backgrounds politicians come from? Should scholars and activists pay attention to the occupational makeup of political institutions? Industry organizations have long thought so. The first people to collect recurring national data on the aggregate occupational makeups of state legislatures in the U.S. were not scholars of American politics, but researchers at the Insurance Information Institute, an interest group representing dozens of major national insurance companies. In the 1960s and 1970s, the Institute began collecting nationwide data on the occupations that state lawmakers came from, including the number who were actively employed in the insurance industry—presumably in the hopes that those legislators would be especially favorable to policies that benefitted insurers.

Was their hunch right? Do politicians tend to favor the industries they worked in? As it stands, scholars of U.S. politics have only limited evidence. Most research on the personal roots of elite decision making (Burden 2007) and the numerical or descriptive representation of social groups (Pitkin 1967) has focused on characteristics like race and gender (e.g., Berkman and O’Connor 1993; Canon 1999; Griffin and Newman 2008; Swers 2002; Thomas 1991; Whitby 1997). Only a handful of studies have explored whether politicians from different occupations behave differently in office (Carnes 2012; 2013; 2016; Eulau and Sprague 1964; Miller 1995; Witko and Friedman 2008). And although their findings generally suggest that occupations matter, these studies still leave many stones unturned.

Perhaps one of the most pressing weaknesses in the emerging literature on politicians' occupational backgrounds is that most studies have focused on the associations between a legislator's former occupation and how he or she casts roll-call votes. This is a logical place for researchers to begin; data on roll-call voting are easy to obtain and analyze. But just as the literatures on the gender and racial backgrounds of politicians moved from early roll-call 
analyses to research on the consequential but harder-to-study choices that legislators make before the votes are cast, it is probably time for the literature on the occupational backgrounds of politicians to move beyond the low-hanging fruit.

In this paper, we ask whether politicians’ occupational backgrounds are associated with the important work that goes on during the agenda-setting stages of the legislative process (Hall 1996; Kingdon [1984] 2011; Schattschneider 1960). Does the presence or absence of politicians from a given occupational background affect the kinds of bills that are introduced in a legislature? As a test of the hypothesis that lawmakers' occupations can inform the legislative agenda, we focus on the trillion-dollar industry that pioneered quantitative research of the occupational makeup of American legislatures: the insurance industry. From an electoral standpoint, insurance policy can be an unrewarding issue. Insurance-related legislation is often highly technical, the vast majority of insurance legislation receives little or no media attention, and routine insurance bills rarely excite the passions of the general public. ${ }^{1}$ The lawmakers who work on insurance issues are therefore likely to be those who already have expertise and interest in the field—including, we suspect, legislators who have worked in the insurance industry themselves.

Drawing on data from three recent state legislative sessions (2007-08, 2009-10, and 2011-12), we study the 30 states for which we could obtain both information about legislators' occupational backgrounds (either their main occupation before holding office, or for those who were still employed, their main occupation outside of holding office) and data on the bills

\footnotetext{
${ }^{1}$ Of course, high-profile bills like the Affordable Care Act generate far more interest. They are the exception, however, not the rule. The thousands of insurance bills introduced in state legislatures and Congress each year receive far less public attention; they are "normal policymaking” (Burstein 2014).
} 
introduced in each state that affected the insurance industry. Using a mix of human coding and automated text analysis, we classified the insurance bills introduced in these states based on whether they benefitted the insurance industry.

With these data, we then explore whether politicians from the insurance industry affect the legislative agenda on insurance regulation, either by promoting favored legislation (positive agenda control) or by blocking unwanted regulations (negative agenda control). Our analyses find evidence of both. States with more insurance industry employees in their legislatures consider fewer bills regulating the industry overall (Study 1). But the bills that are introduced are disproportionately influenced by former insurers (Study 2), and the bills insurers introduce, while not overwhelmingly favorable to the industry, tend to be more favorable than their colleagues' insurance bills (Study 3).

These findings have important implications for the study of descriptive and substantive representation and the personal roots of elite decision making, and especially the emerging research on the occupational makeup of governments in the U.S. and elsewhere. This study adds new empirical evidence to the growing finding that politicians' occupational backgrounds matter. It studies an occupational group that has never been the subject of past research on politicians' occupational backgrounds; just as scholars have shown that politicians from law, business, and working-class jobs differ from other leaders, this study shows that politicians from insurance seem to stand out as well. Most importantly, this paper is one of the first studies to focus exclusively on how occupational backgrounds matter in the agenda-setting process, not just during the roll call votes that have more often been the subject of academic research. And this study goes further than past research on occupations and agendas by taking seriously the distinction between negative and positive agenda control, a point that has so far been overlooked 
in the emerging research on the occupational backgrounds of politicians. This study supports the emerging consensus that it does, in fact, matter what professional backgrounds politicians come from—and suggests that scholars interested in this topic would do well to focus more carefully on how the occupational makeup of political institutions can affect which problems and policies ultimately make it onto the government's agenda.

\section{Agenda Setting and Occupations}

The legislative agenda — the set of problems lawmakers hope to act on and the set of policies they are considering to solve them-is one of the most important sites of power in the policymaking process. If lawmakers are unwilling to entertain a given policy, it cannot be considered or debated, let alone enacted. If they are uninterested in a problem, government interventions to solve it stand little chance of getting off the ground.

Scholars of legislative politics have long recognized that the government's agenda depends at least in part on the personal views and backgrounds of legislators. Of course, crises, unexpected events, and sudden shifts in public opinion sometimes force problems or policies into the spotlight. Lawmakers sometimes sponsor bills, work on committees, and participate in floor debates in the hope of building reputations that constituents, donors, interest groups, and party leaders will view favorably (Hansen and Treul 2015; Kollman 1998; Koger 2003; Weingast and Marshall 1988). However, lawmakers also routinely champion causes that they have some special expertise in, or some personal connection to (Burden 2007; Fenno 1973; Hall 1996; Kingdon [1984] 2011; Krehbiel 1991; Mayhew 2000; Schiller 1995; Wawro 2000). That is, lawmakers often fight for proposals that they know more about or care more about. 
The proposals lawmakers know and care about are in turn often correlated with their personal backgrounds and life experiences (Burden 2007). For example, black lawmakers work harder than their white colleagues to promote legislation on issues that affect the black community (Bratton and Haynie 1999, Grose 2011) while women in legislatures work harder to promote legislation on women's issues (Little, Dunn, and Deen 2001; Swers 2002). The numerical or descriptive representation of many social groups seems to affect whether their concerns are mirrored in the legislative agenda.

Is the same true for occupational groups? Do legislators from different lines of work champion different kinds of bills? Occupational backgrounds differ from other demographic and social characteristics in important ways; race and gender are not the same as occupation (most notably, because occupations are far more fluid and self-selected). However, there are still theoretical reasons to expect politicians from different occupational backgrounds to know and care about different subjects (albeit it for reasons that have less to do with experiences rooted in immutable characteristics). People from different occupations often tend to have different views, especially on issues that directly pertain to their industries. This may be because they have different material or political incentives; a simple capture model would predict that legislators from a given industry would have personal financial incentives (e.g., the revolving door) or political incentives (e.g., campaign contributions from lobbyists) to promote new laws that favor the industry, as scholars of bureaucracy recognize (see Carpenter 2014).

Alternatively, lawmakers’ careers might simply socialize them to prioritize different problems and to think differently about proposed solutions. Cultural capture models would predict that legislators from a given industry would work to promote it, not because of personal material interests, but because their experiences in the industry shaped their perceptions about 
what constitutes good public policy (Kwak 2014, Jansa and Gray 2017). Or lawmakers might even be motivated to act on behalf of their industries due to a more conscious feeling of shared identity with their occupational group. ${ }^{2}$ A retired public school teacher serving in the legislature might fight to increase teacher salaries, not because she expects to benefit personally, but because her time working as a teacher influenced her personal opinion on how much teachers should be paid or left her with a feeling of solidarity with today's educators.

Whatever the exact mechanism, lawmakers from different occupations may well bring different priorities to the agenda-setting process. Do they?

\section{Advancing Research on Lawmakers’ Occupational Backgrounds}

To date, there has been almost no research on the links between the occupational backgrounds of politicians and the agendas that political institutions pursue. In general, research on the descriptive representation of occupational groups has been somewhat sporadic. In the 1960s, there was a burst of scholarship on the careers and social circles politicians were drawn from (e.g., Matthews 1964; Domhoff 1967), but this line of research slowed in the 1970s (for a review, see Putnam 1976) and was more or less dormant until the early 2000s (but see Miller 1995). In the last decade, scholars have taken a renewed interest in this topic (e.g., Bonica 2017; Campbell and Cowley 2014; Carnes 2013; Carnes and Lupu 2015; Sojourner 2013; Witko and

\footnotetext{
${ }^{2}$ In the study of race and politics, researchers have found that minority representatives often work on their group's behalf without expectation of electoral reward (Broockman 2013, Minta 2011). Of course, occupational identities are more fluid—group membership is more changeable - and occupational identities tend to be more individualistic than group-oriented (Deaux et al 1995; Tajfel and Turner 1986) and therefore less likely to inspire action on behalf of the group (Hinkle and Brown 1990). It is at least conceivable, however, that for lawmakers from many industries, a sense of shared professional identity could inspire them to fight for their industry in office.
} 
Friedman 2008). However, this new wave of research on politicians' occupational backgrounds has still left many questions unanswered. Scholars have only examined a handful of occupations. For instance, we know something about politicians from law (Miller 1995; Bonica 2017), business (Witko and Friedman 2008), farming (Bellemare and Carnes 2015), and working-class jobs (Carnes and Hansen 2016), but not other lines of work.

Perhaps more problematic, the recent work on the effects of politicians' occupational backgrounds (or related measures like their wealth or outside income) has focused almost exclusively on just one form of legislative conduct, namely, how lawmakers cast roll call votes (Carnes 2012; 2016; Eulau and Sprague 1964; Grose 2013; Griffin and Anewalt-Remsburg 2013; Kraus and Callaghan 2014; Witko and Friedman 2008). This is an understandable choice. Rollcall voting is far easier to measure than agenda-setting activities like introducing bills (Hall 1996). Moreover, many studies have found important links between occupation and roll calls. Just as ordinary citizens from different occupations often have different views about economic issues, lawmakers from different occupational backgrounds tend to vote differently on economic legislation. However, contemporary research has stopped short of asking whether the occupational differences in how legislators vote are also apparent when they do the important work of crafting bills, advocating problems, and setting the legislative agenda.

The rare studies that have broached the subject have had significant (and admitted) methodological limitations. One approach has been to focus on the issues lawmakers work on, but not the stances they take. For instance, Carnes (2013, ch. 3) used data on the bills members of Congress introduce and the numbers of cosponsors they recruit to show that legislators from working-class occupations work harder to promote domestic economic policies. However, as the study notes, the research design could only identify the issues each bill addressed (e.g., economic 
policy vs. agricultural policy), not the actual policy implications of each proposal (e.g., proworker vs. pro-business proposals).

A second approach has been to ask whether legislators are disproportionately likely to serve on committees that regulate the industries they work in (or worked in in the past). This research has found clear evidence that legislators seek out committee assignments related to their current or former industries (e.g., Battista 2012; Buchanan 1962; Hamm, Hedlund and Post 2011; Renzulli and Center for Public Integrity 2002). But as these studies often note, data on committee appointments is not the same as data on the actual policies or proposals legislators pursue. In principle, at least, a lawmaker who worked in health care might use a seat on a healthrelated committee to increase taxes and regulation on health care providers.

Whereas most prior research on the occupational backgrounds of politicians has focused on committee assignments or numbers of bills introduced, in this paper we analyze the links between legislators' occupations and both the volume and direction of new legislation on relevant issues. That is, we go beyond past research, which has asked whether legislators from a given occupational background are more likely to introduce related bills or join related committees. We ask whether legislators from a given occupational background are more likely to give their former or current industry not just more legislation, but the kind of legislation that it wants.

This approach has the advantage of allowing us to study both negative and positive agenda control. When a group or industry wants to exert positive agenda control—getting preferred policies or problems onto the government's agenda-existing measures of legislative effort (number of bills, number of cosponsors, and so on) should capture that phenomenon, albeit somewhat imprecisely. But for many groups and industries, negative agenda control—preventing 
undesirable ideas or proposals from ever getting serious consideration in government (Bachrach and Baratz 1962; Baumgartner et al. 2009; Schattschneider 1960)—is just as important.

If a social group or industry wants a mix of both positive and negative agenda control, studying legislative effort alone may lead us astray. Suppose, for instance, that farmers-turnedlegislators fight harder than other members for new farm subsidies but are also less likely than other members to introduce bills regulating food safety in agricultural production. In this case, a simple measure of total legislative effort might suggest that farmer-legislators introduce about as many agricultural bills as other members on average—and lead researchers to wrongly conclude that farmer-lawmakers are just like other members. By studying both the aggregate volume of legislation introduced on a given issue (which can capture instances when negative agenda control outweighs positive agenda control, or vice versa) and the direction or substance of individual bills (which can be either beneficial or harmful to a given industry), our research captures a wider range of agenda-setting behaviors.

\section{Insurance and State Legislative Agendas}

To test the idea that lawmakers’ occupational backgrounds influence their agenda-setting activities, we focused on state legislators who had previously worked in the insurance industry. Why insurance? For one, the industry is large and important. The U.S. has the largest private insurance industry in the world, and its annual revenues usually exceed \$1.2 trillion. Over two million Americans are employed in insurance, and insurance makes up about $40 \%$ of the financial sector (Millard 2015).

Second, the insurance industry has long sought to influence public policy, and a major interest group representing the industry, the Insurance Information Institute, collected data on the 
occupational backgrounds of U.S. politicians in the hopes of doing so. In that sense, it is a good starting point for research on occupational backgrounds and agenda setting and, in fact, a crucial case for our argument. If any occupational background influences legislative agenda setting, it should be a background in insurance.

Third, and related, we suspect that if legislators from insurance backgrounds somehow influence the agenda-setting stage, legislators from other large, well-organized industries might have similar effects on agenda-setting that could be investigated in future research. The insurance industry is deeply influenced by public policy and highly attentive to who holds office. Of course, many politicians hail from occupational backgrounds in industries that are less wellorganized and less focused on government (e.g., legislators working in the non-profit or service sectors). But politicians from any large, well-organized industry that regularly monitors and courts elected officials—real estate, agriculture, finance, health care, and so on-may well exhibit similar behaviors.

Do lawmakers who worked in insurance differ in how they attempt to shape the legislative agenda? Do they try to make the insurance industry’s agenda the government's agenda? In this paper, we focus on state legislatures. States are ideal for our purposes for several reasons. State agendas are 50 times more numerous than the federal agenda, and far more varied. The occupational makeups of state legislatures also vary far more than the makeup of federal offices (Carnes 2013). Unlike county and local governments, states have significant agendasetting powers, and their agendas can be studied far more readily.

And — perhaps most importantly_-state governments make many of the most important policy decisions pertaining to the insurance industry. States license insurance companies and individual insurance producers (also known as insurance agents or brokers). They also regulate 
insurance markets, insurance company finances, and insurance products (often setting caps on premiums and defining crucial concepts like what constitutes “reasonable and fair" information or which policies contain gaps that might be misunderstood by consumers). States have remained the primary drivers of insurance regulation even after the significant changes made to insurance markets under the Affordable Care Act. ${ }^{3}$ Often, individuals and organizations must purchase insurance policies from in-state providers who conform their policies to meet state requirements. If a legislator's occupation matters for any issue, it should be insurance-and if an insurance background matters in any institutional context, it should matter in state legislatures. ${ }^{4}$

Unfortunately, the Insurance Information Institute no longer publicly shares its data on the aggregate occupational makeup of state legislatures (and has never shared its data on the occupations of individual lawmakers). To determine whether legislators from insurance backgrounds were more likely to promote insurance's agenda in the legislature, we collected data describing the occupational makeup of each state's legislature over the span of two decades from state legislative websites, online historical databases, published legislative manuals, and state directories. ${ }^{5}$ These occupational data captured the main occupations that each legislator held outside of office, both while they were serving (for state lawmakers who hold outside jobs) and

\footnotetext{
${ }^{3}$ In the 2012 Supreme Court decision National Federation of Independent Business v. Sebelius, the Court declined to subject health insurance markets to Congressional regulation under the Interstate Commerce Clause, as the Obama Administration had argued to justify the constitutionality of the ACA.

${ }^{4}$ Bureaucratic agencies also make rules guiding insurance regulation. In 11 states, (partisan) statewide elected insurance commissioners head state insurance agencies. However, legislatures in all states consider and adopt legislation regulating insurance markets as well.

${ }^{5}$ Previous efforts to collect data on legislators' occupations (e.g., Maddox 2004, Battista 2012) have relied on a database of state conflict of interest disclosure forms collected by the Center for Public Integrity for a subset of states during the 1999-2000 legislative term. Although these data are more detailed (they include information about every source of income for each legislator), they do not cover the years we use for this analysis.
} 
before (for all lawmakers). ${ }^{6}$ To ensure we were using reliable occupational data, we limited our collection effort to the states that recorded lawmakers' occupations and published that information online or in print. Although we omitted 20 states where officials never collected occupational data or do not maintain historical records, we were more certain about the validity of these data than the data we could have collected from online web searches.

Of course, an analysis of agenda-setting on insurance must be sensitive to both negative and positive forms of agenda-setting. Insurers benefit from some regulations (like the requirement that drivers purchase auto insurance) and shoulder burdens from others (like fines levied to brokers who fail to meet continuing education requirements). On balance, insurers probably favor fewer new regulations overall. But insurers also regularly advocate reforms, changes to licensing requirements, and many other interventions. Against this backdrop, a simple measure of total legislative effort would miss essential features of the way the legislative agenda helps and harms insurance companies. As such, we sought to measure both legislative effort and legislative content.

Using our occupational data, we conducted three related studies to measure (1) the aggregate-level relationship between the number of lawmakers from insurance backgrounds and the amount of legislative effort devoted to insurance issues in the state legislature, (2) whether individual lawmakers from insurance backgrounds were disproportionately likely to introduce or influence the drafting of insurance legislation, and (3) whether the insurance bills introduced by lawmakers from insurance backgrounds were more likely to be favorable to the industry.

${ }^{6}$ The 30 included states are AK, AZ, CA, CO, CT, FL, GA, IA, ID, IL, IN, KS, KY, MA, MD, MI, MN, NC, NE, NJ, NY, NV, OK, PA, SC, TN, TX, WI, and WY. These 30 states came from every region of the country, and there are no obvious differences between these 30 states and the other 20 in terms of population, social diversity, party control of government, state finances, or other potentially relevant variables. 
On balance, we expected to find a negative relationship between the presence of lawmakers from insurance backgrounds and the total volume of legislative effort devoted to insurance. Government regulation is often a burden to the industries being regulated, and we expected to find evidence that lawmakers from insurance backgrounds would exercise some negative agenda control. The more lawmakers from insurance who became state legislators, we reasoned, the less the state legislative agenda would focus on regulating the insurance industry.

Beneath this larger pattern, however, we expected to find evidence of positive agenda control as well. Among the insurance bills that are introduced, we expected former insurers to be heavily involved and we expected them to be disproportionately favorable to the industry. When lawmakers from insurance backgrounds introduced insurance bills, we expected those bills to be more favorable to insurers (relative to the insurance bills introduced by other members). Large, complex industries have incentives to block some regulations and promote others. If lawmakers' occupational backgrounds influence their work at the agenda-setting stage, we should expect legislators from the insurance industry to generally work to keep regulation off the agenda—but also to champion the proposals that insurers want.

\section{Study 1: Do State Legislatures with More Insurers Consider Fewer Insurance Bills?}

We first examined the aggregate-level relationship between the share of insurers in a state's legislature and the volume of new legislation that focused on the insurance industry. Following Gray et al (2005), we used Lexis-Nexis subject term searches to count the number of bills and bill amendments ${ }^{7}$ that addressed insurance-related topics in each state legislature in

\footnotetext{
${ }^{7}$ For most state legislatures, a two-year term begins in an odd year and contains two sessions lasting one year each. Most often, the legislature meets for more days and considers more legislation in the first session of the term, then use the shorter second session only to address the
} 
2007, 2009, and $2011 .{ }^{8}$ We chose these years based on the availability of concurrent occupation and bill count data.

Using our individual-level legislator occupation data, we first created a simple measure of the proportion of lawmakers in each state who had previously or currently worked in the insurance industry. Because our occupational data captured the main or most important occupations a legislator worked, if a legislator reported working in insurance and in other occupations, we still counted him/her as having a professional background in insurance (e.g., a legislator who listed "insurance broker / real estate agent"-the most common compound occupation-would still be counted as having worked in insurance). Of course, this approach could potentially code legislators as insurance professionals even when they only spent a short time working in the industry and spent most of their career elsewhere. Unfortunately, most states do not report how long legislators spent working in each industry. If career professionals are more likely to advance their industry's agenda, then our coding scheme should work against any positive findings by including individuals with weaker personal attachments to the industry in the data.

most pressing issues and pass a budget in advance of an election. Several states have only one session per term. Thus, we only observe agendas in the first session of each term in order to preserve comparability of agendas. For states that begin terms on even years (e.g. New Jersey), we used data from the first session of the term in the year prior to the year of observation (e.g. 2006 data observed for 2007).

${ }^{8}$ We collected state-level data rather than chamber-level data in the hopes of avoiding the inferential errors that might arise if negative agenda control takes place in part through interactions among legislators that span both chambers (e.g., if insurers discourage not just members in their own chamber form taking up anti-industry bills, but also discourage members in other chambers from doing so as well). To account for this possibility, we simply focus on the state legislature as our unit of analysis, rather than the chamber. Doing so sacrifices statistical power, but most of our analyses produce statistically significant results nonetheless. 
We also collected data on several control variables. Because the number of bills introduced can vary drastically from state to state, we collected data on the total number of bills introduced in each state from The Book of the States. Importantly, when we counted the number of bills introduced on each issue using Lexis-Nexis, our search results counted both bills and amendments. The Book of the States, on the other hand, counted each numbered bill only once. Even so, we considered this a reasonable way to control for state-to-state differences in the total size of the legislative agenda. ${ }^{9}$

State lawmakers might introduce more legislation related to a certain industry when the industry makes up a greater share of the state's economy. For example, Iowa is likely to consider more agriculture legislation each year than Connecticut. As such, we controlled for the size of the insurance industry in each state using American Community Survey data on the total proportion of citizens employed by insurers. ${ }^{10}$ We also recorded the proportion of the chambers in each legislature that Democrats controlled. ${ }^{11}$ And to account for differences in how actively legislators were lobbied about insurance issues, we controlled for the lobbying capacity of the insurance industry in each state using Gray and Lowery's 2007 data on the number of interest groups lobbying on insurance issues (Lowery et al. 2012).

Figure 1 plots the basic relationship between the number of insurance-related bills and amendments introduced in each state (on the vertical axis) and the share of state lawmakers with professional experience in the insurance industry (on the horizontal axis). Consistent with our

\footnotetext{
${ }^{9}$ Data summarizing the occupational composition of legislatures, as well as the relative amount of attention each state paid to insurance, is presented in Table A1 in the appendix.

${ }^{10}$ We followed Battista (2013) in using the American Community Survey’s finance and insurance industry category to measure insurance employment statistics.

${ }^{11}$ Our results were the same when we used Berry et al's (1998) measure of government ideology.
} 
Figure 1: Do State Legislatures with More Insurers Consider Less Insurance Legislation?

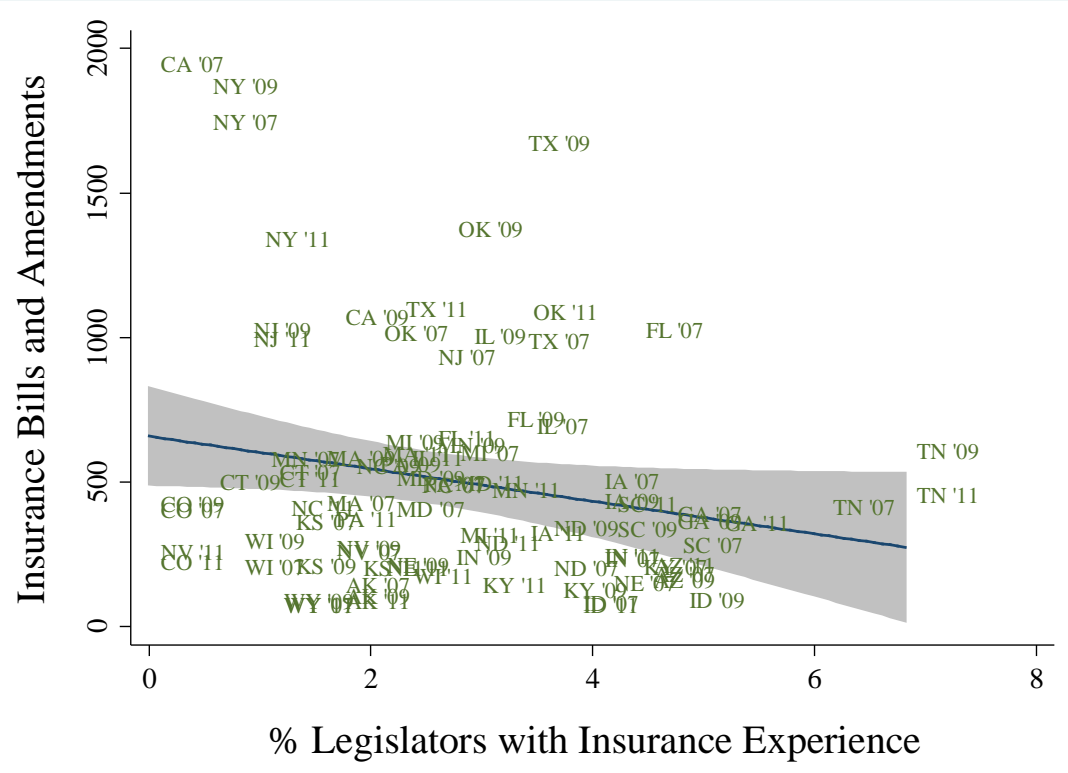

Source: Authors' data collection.

expectations, in states with more insurers in their legislatures, insurance made up a smaller share of the legislative agenda.

Of course, the occupational makeup of government could be associated with a wide range of other factors that might drive the legislative agenda. Maybe states with lots of insurers in their legislatures are also states where insurance is a major industry, where Republicans hold more seats, where insurers lobby legislators more vigorously, or where legislatures are more professionalized. To check for these kinds of confounding variables, we estimated three negative binomial regression models reported in Table 1, one without controls, one with controls for the year and the total number of bills introduced in each state legislature, and one with all the controls described above. 
Like Figure 1, the models related the number of insurance bills and amendments introduced in each state legislature to the percentage of lawmakers who had worked in insurance. The first model simply regressed the size of the insurance agenda in each state on the share of legislators from insurance backgrounds. As in Figure 1, the relationship was negative and statistically significant; compared to a state with no insurers in its legislature, a state legislature with five percent insurers considered roughly 270 fewer insurance bills and amendments on average. $^{12}$

In the second model, we added the total number of bills introduced in each legislature (as an offset variable) to account for the fact that some states consider more bills in general. We also included year fixed effects, and we clustered standard errors to account for repeated observations of states over time. In the third model, we also added controls for the partisan makeup of the legislature (whether the legislature was controlled by Democrats), lobbying on behalf of the insurance industry (the number of registered groups lobbying on insurance matters in the state), potential pressures from citizens employed in the insurance industry (the percentage of the states' citizens who were employed in insurance), and legislative professionalism. In model 2, the estimated association between occupations and agendas was still negative and substantively large — according to the model, compared to a state with no insurers in its legislature, a state legislature with five percent insurers considered roughly 118 fewer insurance bills and amendments on average—although the association dropped below statistical significance. In model 3 , the association was statistically significant and substantively comparable to model 1 , suggesting that states with five percent insurers considered roughly 472 fewer insurance bills and

\footnotetext{
${ }^{12}$ Visual inspection of Figure 1 suggests the error variance is heteroskedastic, and a BreuschPagan test confirms it is. We ran all models in Table 1 by transforming the dependent variable to its $\log$ value. However, doing so made only minor differences to the substantive results.
} 
Table 1: Negative Binomial Regression Models Relating the Volume of Insurance Legislation to the Share of State Lawmakers from Insurance Backgrounds

(1)

Percent of lawmakers
from insurance
Percent of population
employed in insurance
Democratic control of
state legislature (ind.)

Number of insurance

lobbying groups

Legislative

professionalism

Year fixed effects

Total \# of bills (offset)

Intercept

$N$

BIC

No
$-0.11^{*}$

(0.05)

(2)

(3)

$-0.03$

(0.06)

$-0.14 *$

(0.07)

$-0.14 *$

(0.06)

$-0.49+$

(0.28)

0.00

(0.00)

$-0.04$

(0.06)

Yes

Yes

Yes

Yes

No

$6.50 *$

(0.14)

3.25*

4.40*

(0.20)

(0.59)

89

89

1243.07
83

1163.97

Source: Authors' data collection.

Notes: Models 2 and 3 use robust standard errors clustered by state. Missing observations in Model 3 are due to missing data for party control in Nebraska and legislative professionalism.

$+\mathrm{p}<0.10,{ }^{*} \mathrm{p}<0.05$, two tailed 
Figure 2: When Insurers Hold More Seats, Legislatures Consider Fewer Insurance Bills

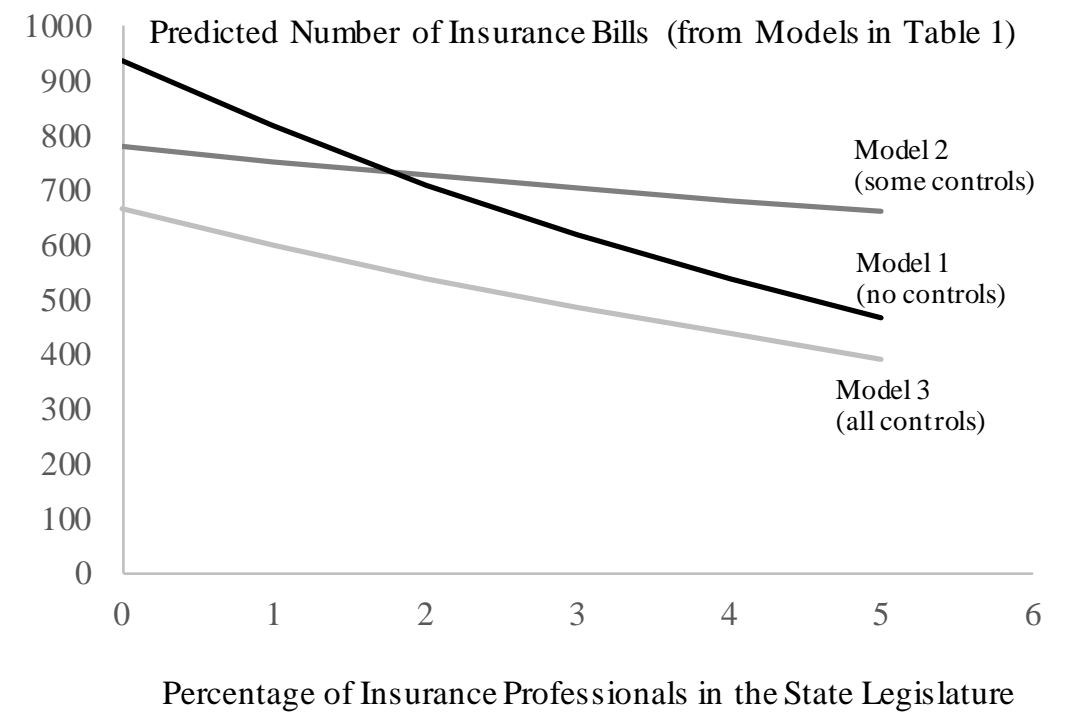

Source: Authors' data collection.

amendments on average relative to states with no insurer-legislators. (The average number of insurance bills considered by a state in this sample was 516.$)^{13}$

Figure 2 plots predictions from the models in Table 1 graphically. Viewed this way, it is easy to see the differences across each of the three models' results, but also the larger pattern that is common across the three. In times and places where people from the insurance industry hold more seats in state legislatures, legislatures introduce fewer bills related to insurance. Even when we take into account the size of legislative agenda in each state (models 2 and 3 ) and the role of insurance professionals in the general public and the organized pressure group system (model 3),

\footnotetext{
${ }^{13}$ Model 3 also found that state legislatures with Democratic majorities considered fewer insurance bills on average, that states with more interest groups representing insurance considered fewer insurance bills, and that more professional legislatures considered fewer insurance bills, controlling for other factors in the model. We found a negative relationship between industry size and the volume of legislation, though the association was significant at the 0.10 level of confidence rather than the conventional 0.05 level.
} 
the presence of insurance professionals in the statehouse is associated with significant reductions in the attention legislators pay to the insurance industry.

To check that the results of this analysis generalized beyond the 30 states for which we have occupational data, we also re-ran model 3 using data from the National Conference of State Legislatures, which collected aggregate-level data on the percentage of lawmakers from the insurance industry in each state’s legislature in 2007 (see Table A2 in the Appendix); the association between insurers and insurance bills in this model was statistically indistinguishable from the association in model 3 in Table $1 .{ }^{14}$ To ensure that our findings were not simply a fluke of the way we modeled count data, we re-estimated model 3 in Table 1 using ordinary least squares and Poisson regression, and to check that the cases in the upper left corner of Figure 1 were not driving our results, we re-estimated model 3 omitting the observations for California 2007, New York 2007, and New York 2009 (Table A3 in the Appendix). All three models again found negative associations, and only the ordinary least squares model fell short of conventional thresholds for statistical significance $(p<0.186)$. To account for the fact that the volume of new insurance legislation might depend in part on how much insurance legislation was passed in previous legislative sessions, we re-estimated models 2 and 3 in Table 1 adding controls for the numbers of insurance bills introduced in previous sessions; our main findings were unchanged (see Table A4 in the Appendix). Finally, because our data come from legislative session that overlap with the passage of the Affordable Care Act at the federal level in 2010, we estimated

\footnotetext{
${ }^{14}$ Their data are less precise - the NCSL focuses on each legislator's main occupation (a coding system that will miss some former insurers who re-classified their main job as "legislator" after they took office), whereas we focus on whether a legislator has ever worked in the insurance industry. The sample size in this analysis was also smaller because we had only one year of data. Accordingly, our point estimates were less precise than those in Table 1, but were not statistically distinguishable from them, and still suggested that insurers exercise negative agenda control.
} 
bivariate negative binomial regression models separately for each year in Table A5 in the Appendix to ensure that our results were consistent across each of the individual legislative terms in our dataset. These models found negative associations between the independent and dependent variables in each year, although in two of the years the point estimates were not statistically significant, perhaps because of the small number of observations (30) for each year. Overall, all of our follow-up models found negative associations between insurers and the volume of new insurance laws in state legislatures.

With a small sample and a blunt measure of the state legislative agenda, our data suggested that legislatures with more former insurers tend to spend less time considering insurance regulations. Importantly, these results do not necessarily mean that legislatures with more former insurers introduce fewer insurance bills; our measure of the agenda includes both bills and amendments. As such, these findings suggest that when insurers hold more seats, legislatures spend less time overall debating and regulating insurance-consistent with the idea that former insurers exercise negative agenda control.

\section{Study 2: When Insurance Bills are Proposed, Do Insurers Play an Outsized Role?}

Insurers may not want much government regulation overall. But when it comes to the bills that insurers do want, do lawmakers from the insurance industry exert positive agenda control? One way to find out is to study who influences the insurance bills that are introduced. If insurers use their positions in legislatures to shape the agenda, we would expect that they would discourage many bills (contributing to an overall decline in the number of insurance laws introduced), but also that they would play an outsized role in the insurance bills that are introduced. 
To find out whether this is the case, we turned to more fine-grained data from Open States, an independent, open-source data collection project previously run by the Sunlight Foundation. ${ }^{15}$ Open States aggregates data on state legislative bills, legislators, and actions directly from state legislative websites and makes the data available for bulk downloads using their API. Using Open States’ data, we searched for all legislation concerning the insurance industry introduced in the 30 states for which we have occupational data, this time focusing on the 2011-2012 legislative term (for which Open States has the most complete data on the bills introduced in each state). ${ }^{16}$

Using the search term "insur" in the API’s search parameter, we first identified the 3,706 bills related to insurance regulation introduced in our 30 states during the 2011-2012 legislative term. ${ }^{17}$ We then downloaded information about each bill, including its state and chamber of origin, bill number, title, full-text URL, and its sponsors and cosponsors. We then matched each bill's sponsors and cosponsors to our list of insurance professionals, and we coded each bill for whether insurance professionals were involved in its introduction. For bills introduced by committees (not individual legislators), we coded whether an insurance professional was a member or chair of the committee.

${ }^{15}$ Available online from http://www.openstates.org (accessed on June 28, 2017). ${ }^{16}$ Unfortunately, Open States has only partial data for the terms before and after (2009-10 and 2013-14), and it does not currently have any data for other terms.

${ }^{17}$ We used the stem for the word to identify bills that combine the stem with various affixes, such as "insurance," "insurer" and "insurable." Open States also tags insurance bills, but we opted to use our own search term. The tags are borrowed from varying state definitions of what constitutes an insurance-related bill, and a simple comparison of the tagged and searched bills suggested that the state-created tags missed many relevant bills. To make sure we weren't missing any relevant bills, we conducted additional searches in a subset of states with the terms "guaranty", "indemni-" (indemnification), and "underwrit-" (underwriting). These terms were chosen because they have few common uses outside insurance, unlike the terms "coverage," "assurance," or "warranty" that may generate many false positives. These terms yielded vanishingly few hits, and the few hits we did find were also included in the results for "insur-". 
Table 2: Are Insurer-Legislators More Involved in Insurance Bills?

\begin{tabular}{lcc} 
Insurance professional was... & $\begin{array}{l}\text { No. of } \\
\text { Bills }\end{array}$ & $\begin{array}{l}\% \text { of } \\
\text { Bills }\end{array}$ \\
\hline $\begin{array}{l}\text { Primary sponsor } \\
\text { Cosponsor }\end{array}$ & 234 & $6.31 \%$ \\
& 153 & $4.13 \%$ \\
Chair of sponsoring committee & 54 & $1.46 \%$ \\
Member of sponsoring committee & 45 & $1.21 \%$ \\
& & \\
Total & $\mathbf{4 8 6}$ & $\mathbf{1 3 . 1 1 \%}$ \\
& & \\
Avg. pct. of insurers in legislature & & $2.56 \%$ \\
Avg. pct. of insurers among Republican legislators & & $3.17 \%$ \\
Avg. pct. of insurers among white legislators & $2.84 \%$ \\
Avg. pct. of insurers among male legislators & $3.07 \%$ \\
Avg. pct. of insurers among legislators with 10+ years exp. & & $3.02 \%$ \\
\hline
\end{tabular}

Source: Authors' data collection. Rows are treated as mutually exclusive in descending order. That is, if insurers were among the primary sponsors and cosponsors on a bill, it would be counted among the bills that had insurers as their primary sponsors.

Table 2 breaks down the different ways that insurance professional might have been involved in introducing insurance legislation. ${ }^{18}$ Consistent with our expectations, former insurers seemed to play a disproportionate role in the insurance legislation that made it onto state legislatures' agendas. Of the more than 3,700 insurance bills that were introduced in the 30 states, 234 (6.3\%) were sponsored by an insurance professional, 153 were cosponsored by an insurer (4.1\%), and another 99 (2.7\%) were sponsored by committees that were either chaired by insurers or had insurers among their members. Whereas insurers made up between $2 \%$ and $3 \%$ of

\footnotetext{
${ }^{18}$ Table A7 in the appendix reports the state-level percentages of insurer-related bills (the "Total” row in Table 2) and the percentage of insurer-main-sponsored bills (the "Primary sponsor" row in Table 2).
} 
the typical legislature (and other subgroups of legislators that might have disproportionate influence over insurance legislation, like Republicans, men, white legislators, and legislators with more than 10 years of experience), insurer-influenced bills made up more than $13 \%$ of the insurance legislation introduced during this time period. That is, insurers were more than five times as likely to be involved in crafting insurance bills as we would expect based on their numerical representation. Even looking only at bills' primary sponsors, insurers were more than twice as likely to write an insurance bill as we would expect by chance alone.

Of course, the vast majority of bills that affect the insurance industry-87\%—are introduced by lawmakers who do not have backgrounds in the insurance industry. In that sense, concerns about industry capture of insurance regulation are probably overstated. But the occupational background of a legislator still seems to matter in this instance. Insurers may not have absolute control over state-level insurance legislation, but they have an outsized role in the insurance bills that are introduced in state legislatures, consistent with the idea that they exert some positive control over the state insurance agenda.

\section{Study 3: Do Legislators from Insurance Backgrounds Sponsor Industry-Friendly Bills?}

Simply knowing that insurance professionals are disproportionately involved in insurance regulation doesn't necessarily mean that they are steering the regulatory agenda towards outcomes that the industry favors. What kinds of insurance bills do former insurers introduce? To find out, we analyzed the content of the insurance bills identified in Study 2 using a combination of human coding and automated text analysis. We first collected URLs for the full text of all 3,706 of the insurance bills introduced in the 2011-12 legislative in the 30 states for which we have individual-level data on whether lawmakers worked in insurance. We then used 
web scraping software to download the full text of each bill. Broken links and incompatible file formats prevented us from collecting every piece of legislation (and cost us two states entirely, Massachusetts and Oklahoma), but we were ultimately able to gather the text of 3,169 bills ( $86 \%$ of the sample) from 28 states.

If legislators' occupations influence how they behave at the agenda-setting stage, we would expect insurance professionals to sponsor more legislation that moves insurance policy in an industry-friendly direction, and less legislation that moves policy away from industry preferences. Of course, insurance regulation is complex and spans many types of financial products. A bill may contain many different provisions, some favored by the industry and others opposed. In general, however, most insurance bills tend to change government involvement in insurance markets in ways that are either favorable or unfavorable to insurers.

Due to the inherent complexity of legislative text, we did not expect an unsupervised text classification program —one that codes texts in a completely automated fashion — to effectively distinguish between pro-industry and anti-industry bills. Instead we used a supervised classifier, a program that relies in part on human coding. Of the 3,169 bills, we randomly sampled 500 to code ourselves. ${ }^{19}$ Our overarching principle for determining whether a bill was pro- or antiindustry was how the bill affected insurance companies' bottom line. Pro-industry bills included those that used government funds to help individuals purchase insurance, bills that increased government sanctions for consumer insurance fraud, and bills that decreased insurance companies' liability limits. Anti-industry bills included those that required insurers to offer

\footnotetext{
${ }^{19}$ A research assistant coded all 500 bills, then a second coder read a random sample of $10 \%$ of those bills to assess inter-coder reliability. The two coders agreed $70 \%$ of the time, and Cohen's kappa was 0.52 , which suggested that the coding was fairly reliable-and better than expected considering the complexity of the bills in question.
} 
policies covering certain types of medical procedures or services, bills that increased insurers' burden for documenting compliance with regulations, or bills prohibiting business practices deemed unfair by consumer protection advocates. When possible, we searched for media accounts that mentioned the support or opposition of industry groups. When bills were not obviously pro-industry or anti-industry, or did not seem to us to be pertinent to private insurance regulation (e.g., state unemployment insurance bills), we simply coded them as Unknown.

After coding these 500 bills, we then categorized them using multinomial LASSO regression (Tibshirani 1996) to predict whether each bill was pro-industry, anti-industry, or unknown. ${ }^{20}$ That is, we ran a text-classification model that used the language in 400 of our coded bills to identify phrases that distinguished between pro- and anti-industry bills (and unknown bills), then tested the model by using the text of the remaining 100 coded bills to generate textbased predictions of whether the bills were pro- or anti-industry. The model accurately predicted the direction of the bill $73 \%$ of the time, ${ }^{21}$ a fairly high accuracy for complicated texts like insurance regulation bills. ${ }^{22}$ (Moreover, misclassification will only reduce the efficiency of our analyses, thereby reducing the chances that we will find that insurance professionals sponsor more insurance-friendly portfolios of bills.) We then used our trained model to code the remaining 2,669 bills in our sample.

\footnotetext{
${ }^{20}$ We prepared the bill text for analysis by removing punctuation and numerals, stemming words, and excluding stopwords (e.g., "the", "of”). We excluded the resulting features (or words) that appeared in fewer in $5 \%$ of the documents and weighted features using frequency-inverse document frequency (TF-IDF) weights, which give greater weight in the model to features that better distinguish one class of texts from another.

${ }^{21}$ To ensure that bills were not misclassified in some systematic way, we reread the 27 misclassified bills in our test set. We could not detect any meaningful patterns; based on our reading, we suspect that misclassification simply occurred at random.

${ }^{22}$ Precision with respect to pro-industry bills was 0.68 and recall was 0.72 , yielding an F-score of 0.70 . Precision with respect to anti-industry bills was 0.71 and recall was 0.87 , yielding an Fscore of 0.78 .
} 
Using these data on the direction of each bill, we then asked whether insurers were more likely to sponsor or cosponsor bills that were favorable to the insurance industry, and whether insurers were less likely to sponsor bills that were unfavorable to the industry. The results are presented in Table 3. Several patterns immediately stand out. First, consistent with our idea that new insurance legislation is more often unfavorable to industry, a majority of the coded insurance bills in our sample—57\%-were unfavorable to insurance companies. Legislators attempting to protect the insurance industry's interests have good cause to try to reduce the overall volume of new insurance legislation (as we saw in Study 1).

Second, bills that insurers sponsored were almost equally likely to be favorable or unfavorable to the industry. Setting aside bills coded as Unknown (which made up 8.8\% of former insurers bills and 9.7\% of non-insurers' bills), roughly $49 \%$ of insurers' bills were favorable, while 51\% were unfavorable to the industry. This finding lies in contrast with our expectation that bills sponsored by former insurers would be more likely than not to be friendly to industry.

However, insurers were significantly more likely than their colleagues to introduce bills that were favorable to the industry. The bills for which insurers were sponsors, cosponsors, or chairs/members of sponsoring committees were about seven percentage points more likely to be pro-industry than the insurance bills introduced by non-insurers ( $48.8 \%$ vs $41.7 \%$; diff. $=7.1 \%$; $p$ $<0.008$ ). This gap, moreover, may understate the true differences between insurers and other legislators slightly. In our 500 human-coded bills, for instance, insurer-backed bills were nine percentage points more likely to be favorable to industry ( $54.2 \%$ vs. $45.2 \%$; diff. $=9.0 \%$; $p<$ $0.20){ }^{23}$

${ }^{23}$ Table A6 in the Appendix presents complete results for the human-coded sample. 
Table 3: Do Insurers Introduce More Pro-Industry Bills?

\begin{tabular}{lccc} 
& Bills Backed by Insurers & $\begin{array}{c}\text { Bills Backed by } \\
\text { Other Legislators }\end{array}$ & Total \\
\cline { 2 - 4 } Pro-industry & 191 & 1,041 & 1,232 \\
& $(48.8 \%)$ & $(41.7 \%)$ & $(42.7 \%)$ \\
Anti-industry & 200 & 1,454 & 1,654 \\
& $(51.2 \%)$ & $(58.3 \%)$ & $(57.3 \%)$ \\
\hline & & & \\
Total & 391 & 2,495 & 2,886
\end{tabular}

Source: Author's data collection. Cells report counts (with column percentages in parentheses). In a $t$-test, the difference between insurers' bills and other bills was statistically significant at $\mathrm{p}<0.008$.

There are many factors besides a legislator's occupational background that might influence the kinds of insurance bills he or she introduces. Could the results above be driven by some other characteristic common to legislators from insurance backgrounds? To find out, we estimated two logistic regression models. The first simply regressed whether a coded bill was pro- or anti-industry (excluding those coded as Unknown) on an indicator for whether an insurance professional was involved in its drafting (as a sponsor or cosponsor or chair/member of a sponsoring committee).

The second added controls that captured the characteristics of the sponsors of each insurance bill. Many bills had multiple sponsors and cosponsors, of course; as a simple test, we collected data on each bill's primary sponsor ${ }^{24}$ (an approach we felt was more defensible than

\footnotetext{
${ }^{24}$ For bills with multiple primary sponsors, we collected data only on the first-listed primary sponsor. For bills sponsored by committees, we collected data on the committee chair.
} 
averaging the characteristics of sponsors and cosponsors). Our analysis included controls for the characteristics of sponsors' districts that might be relevant to insurance regulation, including district per capita income (in $\$ 10,000$ s), the percent of the district population employed in the finance or insurance industries, and the percent of the district without health insurance. ${ }^{25}$ We also controlled for the personal characteristics of each bill's main sponsor: party affiliation, gender, race/ethnicity (measured simply as whether the member was white and non-Hispanic), and years in office. Of course, some of these controls may themselves be driven by our explanatory variable—e.g., insurers may tend to partner with (or be) Republicans more often because of the party's more lax stance on government regulation. In that sense, this approach represents a conservative estimate of the difference between insurer-backed bills and other legislation.

Our findings are reported in Table 4. In our first model (without controls) insurer-backed bills were about six percentage points more likely to be pro-industry. In our second model (with controls) insurer-backed bills were three percentage points more likely to be pro-industry, although the gap was no longer statistically significant. In the third model, we interacted the occupation of the sponsor with their party, under the suspicion that Republican insurance professionals may be more likely to sponsor pro-industry insurance bills than Democratic insurance professionals. The model's estimates were consistent with this expectation, but the relevant interaction term was not statistically significant.

Overall, it appears that the differences between insurer-backed insurance bills and other insurance bills are not as large as a full-blown industry capture model might predict. In the 201112 legislative term, many of the bills insurers supported imposed new burdens on the industry,

${ }^{25}$ District characteristics are collected from 5-year estimates of the American Community Survey, aggregated to state legislative districts by the private firm Social Explorer. 
Table 4: What Predicts Pro-Industry Bills?

\begin{tabular}{|c|c|c|c|}
\hline & (1) & (2) & (3) \\
\hline Insurer-backed bill & $\begin{array}{l}0.29 * \\
(0.11)\end{array}$ & $\begin{array}{c}0.11 \\
(0.11)\end{array}$ & $\begin{array}{c}0.04 \\
(0.19)\end{array}$ \\
\hline \multicolumn{4}{|l|}{ Sponsor characteristics } \\
\hline Republican & & $\begin{array}{l}0.39 * \\
(0.08)\end{array}$ & $\begin{array}{l}0.38 * \\
(0.09)\end{array}$ \\
\hline $\begin{array}{l}\text { Insurer-backed bill } \\
\text { X Republican }\end{array}$ & & & $\begin{array}{c}0.11 \\
(0.24)\end{array}$ \\
\hline $\begin{array}{l}\text { District per capita income } \\
\text { (in } \$ 10,000 \text { s) }\end{array}$ & & $\begin{array}{l}-0.16^{*} \\
(0.06)\end{array}$ & $\begin{array}{l}-0.16^{*} \\
(0.06)\end{array}$ \\
\hline $\begin{array}{l}\% \text { constituents employed } \\
\text { in insurance or finance }\end{array}$ & & $\begin{array}{l}-0.01 \\
(0.02)\end{array}$ & $\begin{array}{c}0.01 \\
(0.02)\end{array}$ \\
\hline $\begin{array}{l}\% \text { constituents without } \\
\text { health insurance }\end{array}$ & & $\begin{array}{l}-0.00 \\
(0.01)\end{array}$ & $\begin{array}{l}-0.00 \\
(0.01)\end{array}$ \\
\hline Female legislator & & $\begin{array}{l}-0.17 \\
(0.10)\end{array}$ & $\begin{array}{l}-0.17+ \\
(0.10)\end{array}$ \\
\hline White legislator & & $\begin{array}{l}0.37^{*} \\
(0.13)\end{array}$ & $\begin{array}{l}0.38^{*} \\
(0.13)\end{array}$ \\
\hline Years in office & & $\begin{array}{l}-0.00 \\
(0.00)\end{array}$ & $\begin{array}{l}-0.00 \\
(0.00)\end{array}$ \\
\hline Intercept & $\begin{array}{l}-0.33^{*} \\
(0.04)\end{array}$ & $\begin{array}{l}-0.33 \\
(0.24)\end{array}$ & $\begin{array}{l}-0.33 \\
(0.24)\end{array}$ \\
\hline$N$ & 2,886 & 2,839 & 2,839 \\
\hline BIC & 3947.89 & 3872.85 & 3880.59 \\
\hline
\end{tabular}

Source: Authors' data collection and American Community Survey.

$+\mathrm{p}<0.10, * \mathrm{p}<0.05$, two tailed

and many of the bills put forth by non-insurers served to help insurance companies. Moreover, the majority of the bills that insurers sponsored were not friendly to the industry. When it comes 
to agenda-setting, it appears that occupation isn’t destiny. But our findings suggest that occupation plays some role in agenda-setting behavior. The mix of insurance bills that were introduced by insurers were more favorable to the industry than the mix introduced by noninsurers. As industry organizations have long suspected, having your own people in office can help push the legislative agenda (even if only marginally) in your favor.

\section{State Legislative Agendas and the Occupational Makeup of Government}

Taken together, the evidence from these three studies suggests that lawmakers who worked in insurance may in fact alter the legislative agenda in ways that promote what insurers want. State legislatures with more insurance professionals in them tend to spend less time considering new insurance regulations. When states consider insurance bills, however, they are disproportionately introduced by lawmakers from insurance backgrounds. And while former insurers' bills on the whole are not particularly friendly to the industry, they are somewhat more likely to be industry-friendly than the bills their colleagues introduce.

These findings make several key contributions to the existing research on legislators’ occupational backgrounds. First, they suggest that the occupational makeup of government can affect not just roll-call votes, but the legislative agenda itself. They also illustrate how a shift from simply studying legislative effort to studying both legislative effort and legislative content can help to shed light on both positive and negative forms of agenda setting.

When it comes to occupations and agenda-setting, negative and positive agenda-setting go hand in hand. For most sectors of the economy, government regulation is often burdensome, and negative agenda control is often the goal. But favorable legislation is always attractive to every industry. To the extent that a legislator’s occupation or industry affects his or her agenda- 
setting behaviors, we might expect to see both negative and positive forms of agenda control, as lawmakers reflecting their industry's perspective simultaneously seek to minimize regulation while pushing for a few plum proposals.

More broadly, these findings underscore the importance of legislators' occupational backgrounds. Political scientists have written a great deal about the difference women make in office, and the difference racial and ethnic minorities make. Lawmakers from different occupational backgrounds seem to make a difference, too. Our analysis of state legislative agendas suggests that there are indeed notable (albeit small) aggregate-level relationships between the numerical or descriptive representation of different professions and the legislative agendas in American states. The occupational makeup of the people the voters elect may shape one of the most important aspects of the legislative process: the problems and policies that make it onto the agenda.

Of course, this study has a number of limitations that are worth reiterating here. We only have data on three terms worth of legislative agendas, and we only have data from 30 states. The controls in Study 3 cover only primary sponsors, not all legislators involved in each bill's introduction. We have lumped insurance professionals together, setting aside for now potential differences between insurers working in different areas (like health insurance vs. home insurance). And, most importantly, we have focused on just one industry. We have speculated that politicians from other large, well-organized, government-focused industries like finance, agriculture, law, and health care might have similar impacts on the legislative process, but follow-up research and replications will be needed to see whether these findings generalize to lawmakers from other occupational backgrounds. 
It is also worth reiterating that the associations we document sometimes drop below conventional levels of statistical significance, especially in auxiliary models. Models with and without controls find significant negative associations between the numbers of insurance professionals in a legislature and the amount of new legislation affecting insurance, as do auxiliary models that drop outliers (Appendix Table A3), test alternative model specifications (Appendix Table A3), and add lagged dependent variables to the list of controls (Appendix Table A4). However, the negative association between insurance professionals and new insurance legislation falls short of statistical significance in a model with some but not all of our controls (Table 1; Appendix Table A4), three models estimated with data from just a single year (Appendix Table A2; Appendix Table A5), and one model estimated using an alternative OLS model specification (Appendix Table A3). Likewise, we find that insurance professionals introduce insurance bills that are significantly more favorable to industry, but when we control for partisanship and district characteristics, this association falls short of statistical significance (Table 3). On balance, the weight of the evidence is consistent with the idea that insurance professionals discourage industry regulation, play an oversized role in insurance policymaking, and tend to promote more insurance reforms that are favorable to industry. But these nonsignificant findings suggest that additional research is still needed. Data on the occupational backgrounds of politicians are still scarce — especially in state-level analyses, where we are often limited to samples of under 100 . With larger samples, future researchers could more confidently assess the robustness of the findings in this analysis.

Even so, the results reported here are broadly consistent with past research and point clearly to the conclusion that occupations matter. Just as the number of women or people of color in public office affects whether gender and racial issues make it onto the agenda, the number of 
people from different occupations may affect whose voice is heard in our political institutionsas industry organizations have long suspected. 


\section{Bibliography}

Bachrach, Peter, and Morton S. Baratz. 1962. “Two Faces of Power.” American Political Science Review 56(4): 947-52.

Battista, James Coleman. 2012. "State Legislative Committees and Economic Connections: Expertise and Industry Service.” State Politics \& Policy Quarterly 12(3): 284-302.

Battista, James C. 2013. "Financial Interests and Economic Diversity in State Legislatures.” Social Science Quarterly 94(1): 175-99.

Baumgartner, Frank, Jeffrey M. Berry, Marie Hojnacki, David C. Kimball, and Beth L. Leech. 2009. Lobbying and Policy Change: Who Wins, Who Loses, and Why. Chicago: University of Chicago Press.

Bellemare, Marc F., and Nicholas Carnes. 2015. "Why Do Members of Congress Support Agricultural Protection?” Food Policy 50(1): 20-34.

Berkman, Michael B., and Robert E. O’Connor. 1993. "Do Women Legislators Matter? Female Legislators and State Abortion Policy.” American Politics Quarterly 21:102-24.

Berry, William D., Evan J. Ringquist, Richard C. Fording, Russell L. Hanson. 1998. "Measuring Citizen and Government Ideology in the American States, 1960-93.” American Journal of Political Science 42(1): 327-348.

Bonica, Adam. 2017. "Why Are There So Many Lawyers in Congress?” Presented at the annual meeting of the Midwest Political Science Association, Chicago, IL, April 6-9.

Bratton, Kathleen A., and Kerry L. Haynie. 1999. “Agenda Setting and Legislative Success in State Legislatures: The Effects of Gender and Race.” Journal of Politics 61:658-79.

Broockman, David E. 2013. "Black Politicians Are More Intrinsically Motivated to Advance Blacks’ Interests: A Field Experiment Manipulating Political Incentives.” American Journal of Political Science 57(3): 521-36.

Buchanan, William. 1962. “Subject Matter Experts.” In The Legislative System: Explorations in Legislative Behavior, eds. John C. Wahlke, Heinz Eulau, William Buchanan, and Leroy C. Ferguson. New York: Wiley and Sons.

Burden, Barry C. 2007. The Personal Roots of Representation. Princeton, NJ: Princeton University Press.

Campbell, Rosie, and Philip Cowley. 2014. "What Voters Want: Reactions to Candidate Characteristics in a Survey Experiment.” Political Studies 62: 745-765. 
Canon, David T. 1999. Race, Redistricting and Representation: The Unintended Consequences of Black Majority Districts. Chicago: University of Chicago Press.

Carnes, Nicholas. 2012. "Does the Numerical Underrepresentation of the Working Class in Congress Matter?” Legislative Studies Quarterly 37: 5-34.

Carnes, Nicholas. 2013. White-collar Government: The Hidden Role of Class in Economic Policy Making. Chicago, IL: University of Chicago Press.

Carnes, Nicholas. 2016. “Who Votes for Inequality?” In Congress and Policy Making in the 21st Century, eds. Jeffrey A. Jenkins and Eric M. Patashnik. New York: Cambridge University Press.

Carnes, Nicholas, and Eric R. Hansen. 2016. “Does Paying Politicians More Promote Economic Diversity in Legislatures?” American Political Science Review 110(4): 699-716.

Carnes, Nicholas, and Noam Lupu. 2015. "Rethinking the Comparative Perspective on Class and Representation: Evidence from Latin America.” American Journal of Political Science 59(1): $1-18$.

Carpenter, Daniel. 2014. “Detecting and Measuring Capture.” In Preventing Regulatory Capture: Special Interest Influence and How to Limit It, eds. Daniel Carpenter and David A. Moss. New York: Cambridge University Press.

Deaux, Kay, Anne Reid, Kim Mizrahi, and Kathleen A. Ethier. 1995. "Parameters of Social Identity.” Journal of Personality and Social Psychology 68(2): 280-91.

Domhoff, G. William. 1967. Who Rules America? New York: Prentice Hall.

Eulau, Heinz, and John D. Sprague. 1964. Lawyers in Politics: A Study in Professional Convergence. Indianapolis, IN: Bobbs-Merrill.

Fenno, Richard F., Jr. 1973. Congressmen in Committees. New York: Little, Brown, and Co.

Gray, Virginia, David Lowery, Matthew Fellowes, and Jennifer L. Anderson. 2005. "Legislative Agendas and Interest Advocacy: Understanding the Demand Side of Lobbying." American Politics Research 33(3): 404-434.

Griffin, John D., and Brian Newman. 2008. Minority Report: Evaluating Political Equality in America. Chicago: University of Chicago Press.

Griffin, John D., and Claudia Anewalt-Remsburg. 2013. "Legislator Wealth and the Effort to Repeal the Estate Tax.” American Politics Research 41(4): 599-622.

Grose, Christian R. 2011. Congress in Black and White: Race and Representation in Washington and at Home. New York: Cambridge University Press. 
Grose, Christian R. 2013. "Risk and Roll Calls: How Legislators' Personal Finances Shape Congressional Decisions.” SSRN Working Paper 2220524.

Hall, Richard L. 1996. Participation in Congress. New Haven, CT: Yale University Press.

Hamm, Keith E., Ronald D. Hedlund, and Stephanie Shirley Post. 2011. “Committee Specialization in U.S. State Legislatures during the $20^{\text {th }}$ Century: Do Legislatures Tap the Talents of Their Members?” State Politics \& Policy Quarterly 11(3): 299-324.

Hansen, Eric R., and Sarah A. Treul. 2015. "The Symbolic and Substantive Representation of LGB Americans in the U.S. House.” Journal of Politics 77(4): 955-67.

Hinkle, Steve, and Rupert J. Brown. 1990. "Intergroup Comparisons and Social Identity: Some Links and Lacunae.” In Social Identity Theory: Constructive and Critical Advances, eds. Dominic Abrams and Michael A. Hogg. New York: Springer-Verlag.

Jansa, Joshua M., and Virginia Gray. 2017. "Captured Development: Industry Influence and State Economic Development Subsidies in the Great Recession Era.” Economic Development Quarterly 31(1): 50-64.

Kingdon, John W. [1984] 2011. Agendas, Alternatives, and Public Policies. Boston: Little and Brown.

Koger, Gregory. 2003. "Position Taking and Cosponsorship in the U.S. House.” Legislative Studies Quarterly 28:225-46.

Kollman, Ken. 1998. Outside Lobbying: Public Opinion and Interest Group Strategies. Princeton, NJ: Princeton University Press.

Kraus, Michael W., and Bennett Callaghan. 2014. "Noblesse Oblige? Social Status and Economic Inequality Maintenance among Politicians.” PLOS One 9(1): 1-6.

Krehbiel, Keith. 1991. Information and Legislative Organization. Ann Arbor: University of Michigan Press.

Kwak, James. 2014. “Cultural Capture and the Financial Crisis.” In Preventing Regulatory Capture: Special Interest Influence and How to Limit It, eds. Daniel Carpenter and David A. Moss. New York: Cambridge University Press.

Little, Thomas H., Dana Dunn, and Rebecca E. Deen. 2001. “A View from the Top: Gender Differences in Legislative Priorities among State Legislative Leaders.” Women and Politics 22:29-50. 
Lowery, David, Virginia Gray, John Cluverius, and Jeffrey J. Harden. 2012. "Explaining the Anomalous Growth of Public Sector Lobbying in the American States, 1997-2007.” Publius: The Journal of Federalism 43(4): 580-99.

Maddox, H.W. Jerome. 2004. “Opportunity Costs and Outside Careers in U.S. State Legislatures.” Legislative Studies Quarterly 29(4): 517-44.

Matthews, Donald R. 1964. The Social Backgrounds of Political Decision-Makers. New York: Random House.

Mayhew, David R. 2000. America's Congress: Actions in the Public Sphere. New Haven, CT: Yale University Press.

Millard, Sean. 2015. “The US Insurance Industry.” Market Realist. Available online from http://marketrealist.com/2015/02/us-insurance-industry-largest-world/ (accessed on March 30, 2017).

Miller, Mark C. 1995. The High Priests of American Politics: The Role of Lawyers in American Political Institutions. Knoxville: University of Tennessee Press.

Minta, Michael D. 2011. Oversight: Representing the Interests of Blacks and Latinos in Congress. Princeton, NJ: Princeton University Press.

Pitkin, Hannah Fenichel. 1967. The Concept of Representation. Berkeley: University of California Press.

Putnam, Robert D. 1976. The Comparative Study of Political Elites. Englewood Cliffs, NJ: Prentice-Hall.

Renzulli, Dianne, and the Center for Public Integrity. 2002. Capitol Offenders: How Private Interests Govern Our States. Washington: Public Integrity Books.

Schattschneider, E. E. 1975. The Semisovereign People. New York: Holt, Rinehart, and Winston.

Schiller, Wendy J. 1995. "Senators as Political Entrepreneurs: Using Bill Sponsorship to Shape Legislative Agendas.” American Journal of Political Science 39:186-203.

Shor, Boris, and Nolan McCarty. 2011. "The Ideological Mapping of American Legislatures.” American Political Science Review 105(3): 530-51.

Sojourner, Aaron. 2013. "Do Unions Promote Electoral Office-Holding? Evidence from Correlates of State Legislatures’ Occupational Shares.” Industrial and Labor Relations Review 66(2): 467-486.

Swers, Michele. 2002. The Difference Women Make. Chicago: University of Chicago Press. 
Tajfel, Henri, and John C. Turner. 1986. “The Social Identity Theory of Intergroup Behavior.” In Psychology of Intergroup Relations, eds. Steven Worchel and William G. Austin. Chicago: Nelson Hall.

Tibshirani, Robert. 1996. "Regression Shrinkage and Selection via the Lasso.” Journal of the Royal Statistical Society, Series B (Methodological). 58(1): 267-88.

Thomas, Sue. 1991. “The Impact of Women on State Legislative Policies.” Journal of Politics 53:958-76.

Wawro, Gregory J. 2000. Legislative Entrepreneurship in the U.S. House of Representatives. Ann Arbor: University of Michigan Press.

Weingast, Barry R., and William J. Marshall. 1988. “The Industrial Organization of Congress; or, Why Legislatures, Like Firms, Are Not Organized as Markets.” Journal of Political Economy 96:132-63.

Whitby, Kenny J. 1997. The Color of Representation: Congressional Behavior and Black Interests. Ann Arbor: University of Michigan Press.

Witko, Christopher, and Sally Friedman. 2008. "Business Backgrounds and Congressional Behavior." Congress \& the Presidency 35: 71-86. 


\section{Appendix}

Table A1: Descriptive Statistics: The percentages of legislators from insurance backgrounds and the ratio of insurance bills to the overall size of the legislative agenda.

\begin{tabular}{|c|c|c|c|c|c|c|}
\hline \multirow[t]{2}{*}{ State } & \multicolumn{3}{|c|}{ Pct. Legislators } & \multicolumn{3}{|c|}{ Agenda Ratio } \\
\hline & 2007 & 2009 & 2011 & 2007 & 2009 & 2011 \\
\hline AK & 1.67 & 1.67 & 1.67 & 0.33 & 0.20 & 0.24 \\
\hline AZ & 4.44 & 4.44 & 4.44 & 0.13 & 0.13 & 0.16 \\
\hline CA & 0 & 1.67 & 0.83 & 0.40 & 0.44 & -- \\
\hline $\mathrm{CO}$ & 0 & 0 & 0 & 0.63 & 0.53 & 0.32 \\
\hline CT & 1.07 & 0.53 & 1.07 & 0.14 & 0.17 & 0.16 \\
\hline FL & 4.38 & 3.13 & 2.5 & 0.46 & 0.33 & 0.34 \\
\hline GA & 4.66 & 4.66 & 5.08 & 0.32 & 0.32 & 0.38 \\
\hline ID & 3.81 & 4.76 & 3.81 & 0.15 & 0.15 & 0.13 \\
\hline IL & 3.39 & 2.82 & 2.26 & 0.12 & 0.14 & 0.09 \\
\hline IN & 4.00 & 2.67 & 4.00 & 0.17 & 0.18 & 0.41 \\
\hline IA & 4.00 & 4.00 & 3.33 & 0.18 & 0.33 & 0.24 \\
\hline KS & 1.21 & 1.21 & 1.82 & 0.37 & 0.29 & 0.31 \\
\hline KY & 4.35 & 3.62 & 2.90 & 0.26 & 0.17 & 0.22 \\
\hline MD & 2.13 & 2.13 & 2.66 & 0.16 & 0.19 & 0.21 \\
\hline MA & 1.50 & 1.50 & 2.00 & 0.07 & 0.09 & 0.09 \\
\hline MI & 2.70 & 2.03 & 2.70 & 0.23 & 0.23 & 0.15 \\
\hline MN & 1.00 & 2.49 & 2.99 & 0.12 & 0.14 & 0.15 \\
\hline $\mathrm{NE}$ & 4.08 & 2.04 & 2.04 & 0.21 & 0.32 & 0.29 \\
\hline NV & 1.59 & 1.59 & 0 & 0.22 & 0.27 & 0.24 \\
\hline $\mathrm{NJ}$ & 2.5 & 0.83 & 0.83 & 0.15 & 0.16 & 0.16 \\
\hline NY & 0.47 & 0.47 & 0.94 & 0.11 & 0.12 & 0.09 \\
\hline NC & 2.35 & 1.76 & 1.18 & 0.14 & 0.21 & 0.24 \\
\hline ND & 3.55 & 3.55 & 2.84 & 0.22 & 0.30 & 0.35 \\
\hline $\mathrm{OK}$ & 2.01 & 2.68 & 3.36 & 0.90 & 1.10 & 1.11 \\
\hline PA & 2.37 & 1.98 & 1.58 & 0.13 & 0.16 & 0.11 \\
\hline SC & 4.71 & 4.12 & 4.12 & 0.22 & 0.18 & 0.32 \\
\hline $\mathrm{TN}$ & 6.06 & 6.82 & 6.82 & 0.09 & 0.13 & 0.11 \\
\hline TX & 3.31 & 3.31 & 2.21 & 0.16 & 0.23 & 0.19 \\
\hline WI & 0.76 & 0.76 & 2.27 & 0.25 & 0.19 & 0.14 \\
\hline WY & 1.11 & 1.11 & 1.11 & 0.16 & 0.46 & 0.22 \\
\hline
\end{tabular}

Notes: Percent legislators is the number of state legislators with work experience in the insurance industry divided by the total number of legislative seats in both chambers. Agenda ratio the count of insurance-related bills and amendments in the state from Lexis-Nexis divided by the count of introduced bills from the Book of the States. Because these data are from different sources, the agenda ratio score should be interpreted as an indicator of relative attention rather than a percent of the state's total agenda devoted to insurance. 
Table A2: Negative Binomial Regression Models Relating the Volume of Insurance Legislation to the Share of State Lawmakers from Insurance Backgrounds for 2007

\begin{tabular}{|c|c|c|}
\hline & (1) & (2) \\
\hline Percent of lawmakers & $-0.14^{*}$ & -0.05 \\
\hline from insurance & $(0.07)$ & $(0.05)$ \\
\hline Percent of population & $-0.14^{*}$ & 0.01 \\
\hline employed in insurance & $(0.06)$ & $(0.07)$ \\
\hline Democratic control of & $-0.49+$ & -0.37 \\
\hline state legislature (ind.) & $(0.28)$ & $(0.23)$ \\
\hline Number of insurance & 0.00 & 0.00 \\
\hline lobbying groups & $(0.00)$ & $(0.00)$ \\
\hline Legislative & -0.04 & -0.00 \\
\hline professionalism & $(0.06)$ & $(0.05)$ \\
\hline Year fixed effects & Yes & $\mathrm{n} / \mathrm{a}$ \\
\hline Total \# of bills (offset) & Yes & Yes \\
\hline \multirow[t]{2}{*}{ Intercept } & $4.40^{*}$ & 3.49 \\
\hline & $(0.59)$ & $(0.41)$ \\
\hline Data Source & Authors & NCSL \\
\hline Years & ‘07, ‘09, ‘11 & ‘07 \\
\hline$N$ & 83 & 49 \\
\hline$B I C$ & 1163.97 & 692.17 \\
\hline
\end{tabular}

Source: Authors' data collection and NCSL.

Notes: Standard errors in parentheses. Nebraska is excluded in both models because party control cannot be measured in its nonpartisan legislature. Missing observations in Model 1 are due to missing data for legislative professionalism.

$+\mathrm{p}<0.10,{ }^{*} \mathrm{p}<0.05$, two tailed. 
Table A3: Models Replicating Model 3 in Table 1 Using Alternatives to Negative Binomial Regression

\begin{tabular}{|c|c|c|c|c|}
\hline & $\begin{array}{l}\text { Negative } \\
\text { Binomial }\end{array}$ & $\begin{array}{c}\text { Ordinary } \\
\text { Least Squares }\end{array}$ & Poisson & $\begin{array}{l}\text { Neg. Bin. } \\
\text { (Omitting } \\
\text { Potential } \\
\text { Outliers) }\end{array}$ \\
\hline $\begin{array}{l}\text { Percent of lawmakers } \\
\text { from insurance }\end{array}$ & $\begin{array}{l}-0.14^{*} \\
(0.07)\end{array}$ & $\begin{array}{l}-16.63 \\
(18.66)\end{array}$ & $\begin{array}{l}-0.16^{*} \\
(0.08)\end{array}$ & $\begin{array}{l}-0.14^{*} \\
(0.07)\end{array}$ \\
\hline $\begin{array}{l}\text { Percent of population } \\
\text { employed in insurance }\end{array}$ & $\begin{array}{l}-0.14^{*} \\
(0.06)\end{array}$ & $\begin{array}{c}-6.85 \\
(22.58)\end{array}$ & $\begin{array}{l}-0.11 \\
(0.07)\end{array}$ & $\begin{array}{l}-0.14^{*} \\
(0.06)\end{array}$ \\
\hline $\begin{array}{l}\text { Democratic control of } \\
\text { state legislature (ind.) }\end{array}$ & $\begin{array}{l}-0.49+ \\
(0.28)\end{array}$ & $\begin{array}{c}-86.52 \\
(114.48)\end{array}$ & $\begin{array}{l}-0.68 * \\
(0.28)\end{array}$ & $\begin{array}{l}-0.47+ \\
(0.28)\end{array}$ \\
\hline $\begin{array}{l}\text { Number of insurance } \\
\text { lobbying groups }\end{array}$ & $\begin{array}{c}0.00 \\
(0.00)\end{array}$ & $\begin{array}{c}3.32 * \\
(1.23)\end{array}$ & $\begin{array}{l}-0.00 \\
(0.00)\end{array}$ & $\begin{array}{c}0.00 \\
(0.00)\end{array}$ \\
\hline $\begin{array}{l}\text { Legislative } \\
\text { professionalism }\end{array}$ & $\begin{array}{l}-0.04 \\
(0.06)\end{array}$ & $\begin{array}{c}55.50 \\
(39.39)\end{array}$ & $\begin{array}{l}-0.05 \\
(0.09)\end{array}$ & $\begin{array}{l}-0.05 \\
(0.06)\end{array}$ \\
\hline Year fixed effects & Yes & Yes & Yes & Yes \\
\hline Total \# of bills & Offset & Control & Offset & Offset \\
\hline Intercept & $\begin{array}{l}4.40 * \\
(0.59)\end{array}$ & $\begin{array}{c}287.30 \\
(208.69)\end{array}$ & $\begin{array}{l}4.38 * * \\
(0.69)\end{array}$ & $\begin{array}{l}4.34 * \\
(0.60)\end{array}$ \\
\hline$N$ & 83 & 83 & 83 & 80 \\
\hline $\begin{array}{l}B I C \\
R \text {-squared }\end{array}$ & 1163.97 & 0.68 & 13367.24 & 1090.28 \\
\hline
\end{tabular}

Source: Authors' data collection.

Notes: Models use robust standard errors clustered by state. Nebraska is excluded because party control cannot be measured in its nonpartisan legislature.

$+\mathrm{p}<0.10,{ }^{*} \mathrm{p}<0.05,{ }^{* *} \mathrm{p}<0.01$, two tailed 
Table A4: Models Replicating Models 2 and 3 of Table 1 including a Lagged DV

(2)

\begin{tabular}{|c|c|c|}
\hline $\begin{array}{l}\text { Percent of lawmakers } \\
\text { from insurance }\end{array}$ & $\begin{array}{l}-0.02 \\
(0.06)\end{array}$ & $\begin{array}{l}-0.13^{*} \\
(0.07)\end{array}$ \\
\hline $\begin{array}{l}\text { Percent of population } \\
\text { employed in insurance }\end{array}$ & & $\begin{array}{l}-0.12 * \\
(0.05)\end{array}$ \\
\hline $\begin{array}{l}\text { Democratic control of } \\
\text { state legislature (ind.) }\end{array}$ & & $\begin{array}{l}-0.41^{*} \\
(0.19)\end{array}$ \\
\hline Number of insurance & & -0.00 \\
\hline lobbying groups & & $(0.00)$ \\
\hline $\begin{array}{l}\text { Legislative } \\
\text { professionalism }\end{array}$ & & $\begin{array}{l}-0.16^{*} \\
(0.07)\end{array}$ \\
\hline $\begin{array}{l}\text { Volume of legislation } \\
\text { in previous term }\end{array}$ & $\begin{array}{c}0.00 \\
(0.00)\end{array}$ & $\begin{array}{c}0.00 \\
(0.00)\end{array}$ \\
\hline Year fixed effects & Yes & Yes \\
\hline Total \# of bills (offset) & Yes & Yes \\
\hline Intercept & $\begin{array}{l}3.06^{*} \\
(0.25)\end{array}$ & $\begin{array}{l}4.02 * \\
(0.39)\end{array}$ \\
\hline $\begin{array}{l}N \\
B I C\end{array}$ & $\begin{array}{c}89 \\
124307\end{array}$ & $\begin{array}{c}83 \\
115303\end{array}$ \\
\hline
\end{tabular}

Source: Authors' data collection.

Notes: Models use robust standard errors clustered by state. Missing observations in Model 3 are due to missing data for party control in Nebraska and legislative professionalism.

$+\mathrm{p}<0.10,{ }^{*} \mathrm{p}<0.05$, two tailed 
Table A5: Bivariate Models for Each Year of Observation Using Negative Binomial Regression

\begin{tabular}{lccc}
\hline & $(2007)$ & $(2009)$ & $(2011)$ \\
Percent of lawmakers & $-0.16^{*}$ & -0.08 & -0.06 \\
from insurance & $(0.08)$ & $(0.08)$ & $(0.08)$ \\
& & & \\
Intercept & $6.67^{*}$ & $6.54^{*}$ & $6.23^{*}$ \\
& $(0.24)$ & $(0.25)$ & $(0.25)$ \\
$N$ & & & \\
BIC & 30 & 30 & 29 \\
& 437.55 & 444.87 & 413.14 \\
\hline
\end{tabular}

Source: Authors' data collection.

Notes: Missing data for California in 2011. * $\mathrm{p}<0.05$, two tailed 
Table A6: Direction of Introduced Bills by Sponsors’ Professional Backgrounds in Human Coded Data

\begin{tabular}{lcc} 
& Insurance Professional & $\begin{array}{c}\text { No Insurance } \\
\text { Professional }\end{array}$ \\
\cline { 2 - 3 } Pro-industry & 32 & 165 \\
& $(54.2 \%)$ & $(45.2 \%)$ \\
Anti-industry & 27 & 200 \\
Unknown & $(45.8 \%)$ & $(54.8 \%)$ \\
& 15 & 61 \\
\hline & $(20.3 \%)$ & $(14.3 \%)$ \\
Total & 74 & 426
\end{tabular}

Source: Author's data collection. Column percentages reported under bill counts. $\chi^{2}=3.31, \mathrm{p}=0.19$. 
Table A7: Are Insurer-Legislators More Involved in Insurance Bills? (Table 2, By State)

$\begin{array}{ccccc}\text { state } & \text { \# ins. bills } & \begin{array}{c}\text { \% involving } \\ \text { insurer }\end{array} & \begin{array}{c}\text { \% insurer } \\ \text { sponsored }\end{array} & \begin{array}{c}\text { \% insurers in } \\ \text { state leg }\end{array} \\ \text { AK } & 20 & 10.0 & 5.0 & 1.67 \\ \text { AZ } & 84 & 8.3 & 8.3 & 4.44 \\ \text { CA } & 90 & 6.7 & 1.1 & 0 \\ \text { CO } & 13 & 0.0 & 0.0 & 0 \\ \text { CT } & 104 & 27.9 & 0.0 & 1.07 \\ \text { FL } & 133 & 6.8 & 6.8 & 4.38 \\ \text { GA } & 61 & 42.6 & 42.6 & 4.66 \\ \text { ID } & 52 & 46.2 & 11.5 & 3.81 \\ \text { IL } & 43 & 39.5 & 0.0 & 3.39 \\ \text { IN } & 60 & 8.3 & 8.3 & 4.00 \\ \text { IA } & 104 & 16.3 & 16.3 & 4.00 \\ \text { KS } & 49 & 42.9 & 2.0 & 1.21 \\ \text { KY } & 78 & 15.4 & 15.4 & 4.35 \\ \text { MD } & 248 & 0.8 & 0.0 & 2.13 \\ \text { MA } & 186 & 10.8 & 10.2 & 1.50 \\ \text { MI } & 157 & 13.4 & 13.4 & 2.70 \\ \text { MN } & 138 & 31.2 & 31.2 & 1.00 \\ \text { NE } & 23 & 26.1 & 26.1 & 4.08 \\ \text { NV } & 35 & 28.6 & 11.4 & 1.59 \\ \text { NJ } & 34 & 2.9 & 2.9 & 2.5 \\ \text { NY } & 232 & 0.4 & 0.4 & 0.47 \\ \text { NC } & 34 & 0.0 & 0.0 & 2.35 \\ \text { ND } & 796 & 1.1 & 1.1 & 3.55 \\ \text { OK } & 211 & 23.7 & 23.7 & 2.01 \\ \text { PA } & 180 & 26.1 & 26.1 & 2.37 \\ \text { SC } & 125 & 18.4 & 18.4 & 4.71 \\ \text { TN } & 160 & 26.3 & 26.3 & 6.06 \\ \text { TX } & 195 & 7.7 & 7.7 & 3.31 \\ \text { WI } & 37 & 54.1 & 54.1 & 0.76 \\ \text { WY } & 24 & 4.2 & 4.2 & 1.11 \\ & & & & \end{array}$

Source: Authors' data collection. Columns report state post abbreviations; the number of insurance-related bills in each state during the 2011-2012 legislative session; the percentage of insurance bills for which a former insurer was a sponsor, cosponsor, committee chair, or committee member (the "Total" row in Table 2); the percentage of insurance bills for which a former insurer was a sponsor; that were sponsored the state-level percentages of insurer-related bills (the "Primary sponsor" row in Table 2); and the percentage of state legislators who had worked in insurance. 